\title{
A NEW LOGICAL PROBLEM OF EVIL REVISITED
}

\author{
J. L. Schellenberg
}

In this article I state concisely the central features of a new logical problem of evil developed elsewhere and take account of a response to this problem recently published in this journal by Jerome Gellman. I also reflect briefly on how theology can play a role in such philosophical discussions.

Jerome Gellman has in a recent issue of this journal responded ${ }^{1}$ to my attempt to produce a new logical problem of evil. ${ }^{2}$ Here I provide a basic explanation of the new problem and reply to Gellman's main points, concluding with some reflections on how theological commitments can affect one's philosophizing about God and evil.

\section{Modeling God}

Many goods lauded by theists - a certain kind of free will is one-require there to be evil or require evil to be permitted. Admiration for such goods might conceivably lead someone to propose that the being of God prior to creation would have to include such goods and so could possibly, or would actually, include evil. ${ }^{3}$ But this is not the view of theists, who instead regard the following proposition as a necessary truth:

Prior Purity (PP): Prior to creation there is no evil in God of any kind.

In other words, what theists hold is that it cannot be that, prior to creation, God is or does anything bad. In my proposed new logical problem of evil

\footnotetext{
'See Gellman, "On a New Logical Problem of Evil."

2See Schellenberg, "A New Logical Problem of Evil." This article developed two approaches to the problem, concerned with modeling God and with God's motives in creation, respectively. Here, for economy and focus and also because Gellman gives it the larger share of his attention, carrying over much of what he says in this context to the other, I will restrict my attention to the first, modeling approach.

"Prior" in "prior to creation" may be taken either logically or temporally.
} 
I sought to show that from PP in conjunction with two other propositions theists must regard as necessary truths, namely

Unsurpassable Greatness (UG): God is the greatest possible being

and

Ontological Independence (OI): No world created by God (or any part of a world) is a part of God,

it deductively follows that there is no evil in the world. ${ }^{4}$

I will not reproduce all the ins and outs of the reasoning; for these see the original article. But here are the main moves, together with some illustrative material not in that article. Call any good for which evil is required or must be permitted an evil-involving good. Assuming the three commitments of theism mentioned above, and extracting some of the content of a proposition that follows from the conjunction of UG and OI-(to a first approximation) that prior to creation all good is already contained in God-we can say this: Corresponding, prior to creation, to every possible evil-involving good $\mathrm{g}$ is a pure instance in God of a shared good-type T; this latter instance is the greatest possible instance of $\mathrm{T}$, and greater than $g$ (g could be, say, someone's forgiveness of their daughter's repentant killer, and T beauty). ${ }^{5}$ Likewise, created worlds without evil-involving goods that more nearly approached the pure and unsurpassable greatness of God by richly modeling it would exceed in greatness worlds including evil-involving goods. It must be so, for the modeling worlds would come closer to the pure goodness of God, which as noted is always greater than any associated evil-involving good. Call such worlds Greater Worlds. Now God could ensure the existence of Greater Worlds and could do so limitlessly (some support for this idea appears in the remaining paragraphs of this section), facilitating for finite creatures an ever nearer approach to God's goodness and doing so in numberless ways. So a reason to instead permit evil in a world could never arise for God: evil in a world might indeed appropriately be regarded by us as no less unthinkable than evil in God.

\footnotetext{
4"World" here normally refers to a reality ontologically distinct from God that depends or would depend for its existence on God's creative activity, if God exists. "The" world (or "this" world or "our" world) is the world in which we live. To allow for flexibility in usage I will not say more than this, though it may be noted that, unless otherwise indicated, what I have in mind when using the term is distinct from the modal notion of possible worlds.

${ }^{5}$ Could the good in God be relevantly unsurpassable even if g were equally great? Must the former good be greater? One reason to think it must be is that no good of that type unrealizable in God could be as basic, as fundamental. If there could be a good not in God or able to be in God but quite outside God that was as basic, as fundamental, then, intuitively, we could no longer say (as we've seen theists must say) that all good is in God. Even if this is mistaken and $\mathrm{g}$ can be as great as the instancing in God of $\mathrm{T}$, because of the modeling possibilities about to be introduced in the text we would still in the end be forced to admit that God has no reason to select $g$ for instantiation rather than some one or other of-or some conjunction of-the modeling goods, new instances of which would, because of UG, be made available ceaselessly.
} 
My notion of modeling here is to be taken broadly. It will be well to note, from the original piece, that a modeling good is "any good that purely resembles or images or mirrors or reflects a pure good in God," and that "while every worldly good instances a higher goodness in God, the modeling goods need not be instances of the goods they model: the latter is but one way in which modeling can occur." ${ }^{\prime \prime}$ So although, say, finite love in a world created by God models divine love by being an instance of love, worldly modeling of divine love could occur in other ways-Greater Worlds could, for example, feature beings whose knowledge and experience of God's love is ever more fully and richly realized. Such worlds too would exhibit a pure-and, if God wished it, a ceaselessly deepening - reflection of the higher good in God.

This ceaselessness is, as noted above, one aspect of the limitlessness mentioned where I say that God could ensure the existence of Greater Worlds limitlessly. And the other is the limitless number of Greater Worlds God could bring into existence. The key point here is that there is no end to the number of avenues leading to a pure knowledge and experience and embodiment of supreme value that an unsurpassably great and rich divine being can open up for finite beings. As I say in the original: "There can, to coin an expression, be new infinites of finite pure goodness infinitely, if their source is God and their task is to reflect the glory and richness of God." 7

It may be that to see the force of this new logical problem of evil, and in particular to feel adequately the weight here of PP, we will need to exercise our imaginations more than we ordinarily do. Mythical tales of heavens and hells as well as some regions of science fiction can help us in the quest to gain some small sense of how wonderfully rich would be the pure goodness - and also any opportunity to share in the pure goodness - of an unsurpassably great divine reality. If we understand by God the deepest, greatest, most fascinatingly rich personal being possible, there would for created beings always be new dimensions of God or of God's creations or of God's projects to get to know or to share. Certainly, we are most familiar with our own mode of being and the goods it enables us to encounter, and so we are naturally drawn to them, despite or even because of their often evil-involving nature. But if we want the truth instead of comfortable familiarity, we will have to admit that there would be no reason for God to be creatively biased in favour of us! We, of course, would prefer a world in which we exist, but our perspective now is one thing, and God's before all creation quite another.

Having said that, some of the goods we do know of already compete quite well, when suitably enlarged, with evil-involving goods, and reflection on them may serve here as a kind of imagination pump. Think, for example, of the grandeur in Handel and Mozart and of the drama in

"Schellenberg, "A New Logical Problem of Evil," 38.

"Schellenberg, "A New Logical Problem of Evil," 40. 
Beethoven. And now imagine that a spiritual universe were designed to be like a glorious piece of music writ large, except with God as the Composer, and that finite persons were given a taste for divine aesthetics or the ability to cultivate it, and able to traverse the wonders of this universe, or even with extreme exertion to enlarge upon it, forever or for a finite period of time. Why should we suppose that anything is missing here that only evil could supply?

\section{Gellman's Critique}

So much for providing a sense of the new logical problem of evil. To respond to it adequately, one would need to get fully acquainted with the original article, but the foregoing description will suffice as a basis for judging the force of Gellman's response, to which I now turn. Gellman homes in on the question whether the new problem circumvents the free will defense. He thinks it at least dubious that it does (the numbering here reflects Gellman's earlier summary of my reasoning): "Schellenberg wants his new logical problem of evil to not be vulnerable to the Free Will Defense offered by Alvin Plantinga. However, it is not at all obvious that this is so. Please note that

(8) God can ensure the existence of greater worlds, and can do so limitlessly (where "greater worlds" contain only pure goods), is equivalent to

(E) God can ensure the existence of any world in which there is no evil." 8

And Plantinga, according to Gellman, has shown that $\mathrm{E}$ is false. But the alleged equivalence here does not hold, and so Gellman's critique is not off to a good start. Greater Worlds are by definition greater than and so distinct from "any world permitting or requiring evil," that they are distinct from worlds without evil in which there being no evil is due to creatures always freely doing good even when they were permitted to freely do evil instead. Thus even if God can ensure the existence of Greater Worlds limitlessly, it does not follow that God can ensure the existence of worlds in which there being no evil is due to creatures always freely doing good - and so it does not follow that God can ensure the existence of just any world in which there is no evil. Gellman's equivalence claim is therefore false, and his suspicion that the free will defence can be applied to the new problem will need to find another basis.

There does not appear to be one in the rest of what he says about free will. Conceding that Greater Worlds, on my conception, must be free of evil-involving goods, and so seeing that more will be required to answer the new logical problem of evil, Gellman runs through various options

${ }^{8}$ Gellman, "On a New Logical Problem of Evil," 442.

9'Schellenberg, "A New Logical Problem of Evil," 39. 
for libertarian freedom in a Greater World, concluding that only a "limited closed libertarian freedom" would be possible ${ }^{10}$ - that is, a freedom to choose between good options but not between good and evil (closed), and a freedom to choose how one will move closer to God but never to fall away (limited):

So, let us assume that in a Schellenberg world people do not have morally significant freedom. If they are to have free will at all, they might still have what I will call "closed libertarian freedom," by which I mean libertarian freedom to choose between good options, without freedom to choose evil. ... [And] we must predicate limited closed libertarian freedom, by which I mean libertarian freedom to choose only among good alternatives, and limited to always striving to higher moral levels. Hence, when a person is faced with good choices that leave him at the same moral level as before, he will choose among them. When faced with choices where some, but not all, signify an advance to a higher moral level, the person will not be free to choose to stay at his present moral level, but will choose to advance. In choosing to advance, the person will be able to choose between good alternatives, each of which signifies moral advance. The person's closed libertarian freedom will be limited in this way. If denizens of a Schellenberg world are to have freedom at all, it must be limited closed libertarian freedom. ${ }^{11}$

Closed libertarian freedom, Gellman admits, "fits very nicely with the modeling approach. ... It is impossible for God to will evil, yet God does have free will to choose between alternatives involving no evil choices. So, we can think of God's free will as the divine analogue of human closed libertarian freedom." ${ }^{12}$ Limited closed libertarian freedom, however, "does not exist in God since God can never choose to advance morally. God is necessarily morally perfect." ${ }^{13}$ Gellman rightly does not regard this as a serious obstacle for the modeling approach: "Yet, we can suppose that human closed libertarian freedom must be limited so that creatures can always be approaching God's goodness by their own choice. This limitation would be God's concession for the sake of implementing the grand divine modeling plan. Limiting closed libertarian freedom for an infinite moral improvement would make for the closest mirroring of God's infinite goodness." 14

So here Gellman is inclined to construe the modeling approach charitably. But he's still not buying it:

It seems that the Modeling Argument could avoid the Free Will Defense only by making such an assessment of the value of limited closed libertarian freedom. However, one might well reject this assessment, and think that the value of worldly good is at its most when chosen in open libertarian

\footnotetext{
${ }^{10}$ Gellman, "On a New Logical Problem of Evil," 443.

${ }^{11}$ Gellman, "On a New Logical Problem of Evil," 443.

${ }^{12}$ Gellman, “On a New Logical Problem of Evil," 443-444.

${ }^{13}$ Gellman, "On a New Logical Problem of Evil," 444.

${ }^{14}$ Gellman, “On a New Logical Problem of Evil," 444.
} 
freedom. Then God would have had to allow significant moral freedom, and we would be back to the Modeling Argument's vulnerability to the Free Will Defense. ... Schellenberg's argument depends on making a specific, controversial judgment about the nature of worldly good. ${ }^{15}$

This is rather quick! By deriving my claims that bear on issues about free will from other more general propositions mentioned in my summary of the new problem above, I have indeed put out of reach such a response: now it is not a situation in which my specific intuition about the value of a certain kind of free will is pitted against the free will defender's, but rather one in which my general judgments about purity, impurity, modeling possibilities, and the absence of a reason for God to permit evil, given modeling possibilities, render the free will defender's judgments inapplicable, or at least prevent them from being straightforwardly applied in the way Gellman imagines. Gellman's response is a bit like a rubber band that suddenly snaps back to its original position. To get where he wants to go, Gellman needs to address those larger claims. The rubber band needs to stretch a little further.

Just as with his first move, Gellman appears to see that more is required of him to answer the new logical problem of evil, and so there is more for me to take into account. He spends some time developing a counterexample, involving the good of personal triumph, to the idea that all types of good are in $\mathrm{God}_{1}{ }^{16}$ which counterexample he thinks threatens the claim from the new problem that, above, I formulated as follows: "Corresponding, prior to creation, to every possible evil-involving good $\mathrm{g}$ is a pure instance in God of a shared good-type T; the latter instance is the greatest possible instance of T, and greater than g." But while Gellman in this context has some insightful things to say about the kind of modeling of divine goods that includes instancing the types of goodness under which they fall, and also about the good of personal triumph, his counterexample does not actually threaten the claim in question. For in the original paper on the new problem I accept that not every type of good is realized in God. The claim under consideration (as expressed here and as it appears in the original) is indeed formulated so as to allow for that: suppose that $\mathrm{g}$ is the good of triumphant mountain climbing; $g$ must fall under some shared good-type $\mathrm{T}$, some good-type God too instances, but there is nothing to prevent $\mathrm{g}$ from also falling under good types less general than $\mathrm{T}$ that are not instanced in God-here Gellman's own example of "succeeding at a difficult task at which one could have failed and enjoying its fruits" will serve. ${ }^{17}$

Gellman considers an "imagined" rejoinder to what he has said which in effect concedes that this is so. In his way of putting it: even if the type of good we call personal triumph is not in God, perhaps all that's required is

\footnotetext{
${ }^{15}$ Gellman, “On a New Logical Problem of Evil,” 444.

${ }^{16}$ Gellman, "On a New Logical Problem of Evil," 446-448.

${ }^{17}$ Gellman, “On a New Logical Problem of Evil," 449.
} 
that "God tokens the category (or categories) of good, call it C, applying to personal triumph in creatures." He adds:

It is just that God tokens $C$ in a different way, not requiring personal triumph. $\mathrm{C}$ only has to be general enough to encompass both the human and the divine tokens. The fact that we might not be able to say quite what $C$ is poses no real problem. After all, we have little grasp of the infinite nature of God and the way goods might inhere in God. In many respects, God is beyond our comprehension. So, from the fact that we might not be able to imagine a C common to both creatures and God, we ought not to conclude there is in God no such good, albeit in a form we cannot visualize. ${ }^{18}$

This is very much along the lines of what I said in the original piece; Gellman's C is my T. Thus it seems to me well and good. So why does Gellman think it won't do? Because of an error of interpretation. He argues that the claim under consideration (that corresponding, prior to creation, to every possible evil-involving good $g$ is a pure instance in God of a shared good-type T, and that the latter instance is the greatest possible instance of $\mathrm{T}$, and greater than $\mathrm{g}$ ) still turns out to be false because the connection between the good of personal triumph and $C$ could not be explanatorily tight enough-specifically, $\mathrm{C}$ does not lend itself to an explanation of what is good about personal triumph - to warrant for the former the description "modeling C."19 Evidently Gellman is assuming that, already at this first stage of my reasoning, in the claim (here) involving $\mathrm{T}$, I am concerned with a connection between possible non-divine goods and goods instanced in God that amounts to the modeling of the latter by the former. But that is not the case. All the claim in question requires is that there be some pure type of goodness in God, however general, that is tokened by goods such as personal triumph and whose instancing in the divine case is also greater than them. Call the divine instance here "the higher good." It is only later in the argument that the notion of modeling is introduced to emphasize how goods not at all like the good of personal triumph, goods that clearly do model the higher good in God, could fill a world that God brings into existence.

Thus even though Gellman is right in his claim that the good of personal triumph could not model any type of good in God, this causes no trouble for me, since the modeling argument does not require that it should be able to do so. Indeed, Gellman thereby helps me make one of the central points of that argument, which is that worlds and goods other than those permitting or requiring evil must be conceived if we want our thoughts to alight on goods modeling the pure good in God.

\section{Theology and the Philosophical Imagination}

I do not know if the new logical problem of evil is insoluble, lending itself to a real proof of the nonexistence of God, or at any rate insoluble without

\footnotetext{
${ }^{18}$ Gellman, "On a New Logical Problem of Evil," 448.

${ }^{19}$ Gellman, 449-450. See especially the middle of 449, where the word "modeling" is used.
} 
a major revision of theistic commitments. Until things have been shown to be otherwise, it is my position that this is so. I developed this problem in part because it seemed to me too easy, at present, to acquiesce in the notion that "the" logical problem of evil had been solved-as if there could only ever be one, the one fine-tuned by Plantinga, which many assume he also solved.

It may seem that my position here is too cavalier, but it also owes something, and more fundamentally, to my serious sense that neither theism nor naturalism have as much going for them as their best-known advocates suppose, and that we may be at a much earlier point in religious investigation than almost everyone supposes. Ideas about a divine reality deserve a measure of awe-perhaps "fear and trembling" would not be going too far - from finite humans so recently evolved. The deepest issues about ultimate realities and evil may not yet have been explored, and it is philosophy's job to keep our nose to the grindstone.

Such an emphasis on intellectual humility in philosophy of religionindeed, any similar emphasis; provide your own - will be hard to live by if theology comes to bear on our philosophizing in the wrong way. ${ }^{20}$ So let me conclude by indicating how this can happen, and how it can prevent arguments like the modeling argument from being taken seriously in quite the ways philosophy demands.

The main point is just that theology can arrest the philosophical imagination. Theology begins from a commitment to the existence of God and so to the idea that this world, our world, has been created by God. If not treated carefully, it can therefore in philosophy lead to the assumption that our world is just the sort of world a God would create and to the shutting down of any enterprise aimed at a thorough and imaginatively free consideration of God's options. The modeling argument, manifestly, needs that enterprise to stay open.

What we see here is a kind of constraint that can come to be placed on our thinking about the nature of God: the constraint imposed by the perhaps unnoticed assumption that a correct understanding of God's nature must cohere with the notion that God would actualize a world at least very similar to ours, right down to the inclusion of physical things and human beings. Call this the Similarity Constraint. Even many philosophers betray such an assumption; it is signaled when, for example, people mistakenly put into the very definition of "God" the idea that God is the creator of the universe, instead of, correctly, the creator of any universe there may be in a world actualized by God, or mistakenly say that God might be expected to be or do such-and-such for human beings instead of, correctly, for such creatures as there may be in a world actualized by God. Gellman

\footnotetext{
${ }^{20}$ Notice that I'm not ruling out that there is a right way-or ways. For example, the various theistic theologies provide detailed pictures of the divine that certainly ought to be considered, along with other options, and may support positions of their own that are worthy of discussion in philosophy. I am advocating a garden in which many flowers are carefully tended, not the notion that all theological ideas must be cast out as weeds.
} 
too slips into the suggestion that God would create human beings. ${ }^{21}$ His label "limited closed libertarian freedom" likewise suggests the influence of the Similarity Constraint. Why not open liberating libertarian freedom?

Now, as I've suggested, the Similarity Constraint may not always be reflectively held. Indeed, I think its influence may often be one of which people are not conscious. Its influence is compatible with theistic philosophers explicitly allowing, in various contexts, that God didn't have to create anything at all, much less anything very similar to this world. I am not denying that this regularly occurs. Nevertheless, when people come to philosophy of religion as committed theists who (as such) accept the view that God would create a world like ours, this can drive their inquiry in ways that prevent them from noticing or giving due weight to various axiological possibilities that might count as evidence against their view. Arguments like the modeling argument offered by the new logical problem of evil, if not over-hastily dismissed, can provide a helpful countering influence, one that enables us to become conscious and clear about what's going on here, and more fully opening us to the thought that God's greatness might demand the creation of a very different world, if God creates at all. This thought, it seems to me, is one that the humility characteristic of good philosophy demands we take seriously.

The idea of God is different in this regard-far more interesting and majestic - than, say, the idea of Santa Claus, which is firmly anchored in the actual world (indeed tied to our planet and its human children). Philosophers should be helping to bring this out. The Similarity Constraint ought to be far less influential in philosophy of religion than it is. Indeed, it ought explicitly to be rejected. Of course this doesn't mean we should all accept atheism, though philosophers of religion who notice and consciously set aside the Similarity Constraint may find that atheism appears in a different light. It does mean we should avoid slipping into an unjustified assumption here, and into the constraint on the imagination that comes with it. Because of the influence of theology, it may sometimes be difficult to avoid doing so. But such an imaginative difficulty is precisely the sort of thing philosophers are committed to overcoming.

Mount Saint Vincent University

\section{References}

Gellman, Jerome. 2015. "On a New Logical Problem of Evil." Faith and Philosophy 30: 439-452. https://doi.org/10.5840/faithphil201592144

Schellenberg, J. L. 2013. "A New Logical Problem of Evil." In The Blackwell Companion to the Problem of Evil, edited by Justin P. McBrayer and Daniel Howard-Snyder (Wiley Blackwell), 34-48. https://doi.org/10.1002/9781118608005.ch3

${ }^{21}$ Gellman, “On a New Logical Problem of Evil,” 444. 